Article

\title{
Survival of Fiber-Reinforced Composite Resin Post-Restored vs. Cast Post-and-Core-Restored Teeth: A Retrospective Clinical Study
}

\author{
Oskar Bunz ${ }^{1, *,+} \oplus$, Darja Iwantschenko ${ }^{2,+}$, Sabrina Tulka ${ }^{3}$, Claudia Barthel-Zimmer ${ }^{4}$ and Andree Piwowarczyk ${ }^{1}$ \\ 1 Department of Prosthodontics, School of Dentistry, Faculty of Health, Witten/Herdecke University, \\ 58455 Witten, Germany; Andree.Piwowarczyk@uni-wh.de \\ 2 Private Practice of Orthodontics, 12437 Berlin, Germany; Darja.Iwantschenko@uni-wh.de \\ 3 Chair for Medical Biometry and Epidemiology, Faculty of Health, Witten/Herdecke University, \\ 58455 Witten, Germany; Sabrina.Tulka@uni-wh.de \\ 4 Department of Operative and Preventive Dentistry, School of Dentistry, Faculty of Health, Witten/Herdecke \\ University, 58455 Witten, Germany; Claudia.Barthel-Zimmer@uni-wh.de \\ * Correspondence: oskar.bunz@uni-wh.de; Tel.: +49-2302-926-665 \\ + Contributed equally.
}

Citation: Bunz, O.; Iwantschenko, D.; Tulka, S.; Barthel-Zimmer, C.; Piwowarczyk, A. Survival of Fiber-Reinforced Composite Resin Post-Restored vs. Cast

Post-and-Core-Restored Teeth: A Retrospective Clinical Study. Oral 2021, 1, 340-349. https://doi.org/ $10.3390 /$ oral1040034

Academic Editors: Gianluca

Gambarini and Francisco Javier Silvestre

Received: 22 September 2021

Accepted: 6 December 2021

Published: 14 December 2021

Publisher's Note: MDPI stays neutral with regard to jurisdictional claims in published maps and institutional affiliations.

Copyright: (c) 2021 by the authors. Licensee MDPI, Basel, Switzerland. This article is an open access article distributed under the terms and conditions of the Creative Commons Attribution (CC BY) license (https:// creativecommons.org/licenses/by/ $4.0 /)$.

\begin{abstract}
Objective: The question of whether classic cast post-and-core (CPC) or fiber-reinforced composite resin posts (FRCP) are the best clinical decision has still not been fully solved. Materials and Methods: One hundred and sixty-two teeth were restored with FRCP, and 162 CPC restored teeth were included in this study with a matched-pair design. In a primary analysis, the survival rates after one year (primary endpoint) were compared. The additional analysis included an evaluation of tooth- and construction-specific variables and an illustration of the survival up to 60 months via Kaplan-Meier curves. Results: FRCP showed lower failure risk considering the definitive prosthetic restoration and tooth type compared to CPC restored teeth. In total, 17 failures were observed in the FRCP group and 35 failures in the CPC group. A 60 -month survival rate of $79.3 \%$ for FRCP and $64.5 \%$ for CPC was observed. Teeth serving as abutments for telescopic dentures were more likely to be affected by failure compared to teeth restored with single crowns. Conclusion: Within the limitations of this study, the FRCP showed a lower failure risk compared to the CPC, considering the definitive prosthetic restoration and tooth type within the observation period.
\end{abstract}

Keywords: cast post-and-core; fiber-reinforced composite resin post; postendodontic reconstruction; retrospective survival rate

\section{Introduction}

Restoration of endodontically treated teeth remains a controversial topic [1,2]. New techniques regarding root canal treatment and increasing requests to preserve the natural tooth have resulted in a growing number of postendodontic treatments. Therefore, reconstruction of non-vital teeth is a common step in dental practice [3] and can increase fracture resistance [4]. At the same time, it has a significant impact on the survival of the tooth [5]. An immediate definitive restoration following a successful root canal treatment prevents microleakage and reinfection of the canal or the apical tissues, respectively [6,7]. However, the type of therapy depends on the individual substance defect and the associated retention for an adhesive abutment [7]. After the significant loss of hard tissue, a root-post-core reconstruction is necessary for the mechanical stability of the inserted restorations [2].

Fiber-reinforced composite resin posts (FRCP) were first described in 1990 [8]. Due to their supposedly simple and practice-oriented handling, they have been used more frequently. A possible reduction in root fractures and the preservation of hard tissue under esthetic conditions are accomplished by a similar modulus of elasticity of post and dentine and the adhesive bonding method $[9,10]$. Nevertheless, the number of clinical studies on FRCP abutments is limited, and the results are partly contradictory [11]. 
Metallic posts or so-called cast post-and-core (CPC) restorations have been used since the 18th century, and in particular, cast-posts are recommended in connection with restorations with higher load $[12,13]$. However, the complication rate of the cast post system leads to the question of whether there is still an indication for this kind of post system. The wide range of therapeutic options and recommendations can be a challenge to the practitioner with regard to postendodontic treatment [14]. The prognosis of the root-post-core assembly depends furthermore on other clinical parameters, such as the prosthetic restoration and tooth type.

The aim of this study was to determine whether CPC has higher survival rates than FRCP regarding the concept of prosthetic restoration and tooth type. This study includes a retrospective clinical comparison of the probability of survival and the complication rate of cast posts compared to fiber-reinforced posts. It also served to identify clinical parameters influencing the survival rate of root-post-core assemblies.

\section{Materials and Methods}

\subsection{Study Design and Data Collection}

This study analyzed data from inserted posts dating from January 2012 to November 2017 (71 months). As part of the clinical student course and other dental departments (Witten/Herdecke University, Witten, Germany), a questionnaire for insertion of fiberreinforced composite resin posts was used (see Supporting Information). In addition to a questionnaire, patients' treatment documents were consulted to assess criteria such as the radiographic status of the tooth. The data of the cast post-and-core system were collected equally in order to be able to compare both systems. Only teeth restored with first-time post restorations were recorded. All teeth had to be asymptomatic. Teeth with insufficient root canal fillings were excluded. In addition, their tooth mobility (Miller Classification) had to be less than class 2, and teeth with acute or untreated periodontitis were excluded. Teeth with surgical procedures such as surgical crown lengthening, hemisection or dental root surgery after post insertion were included. In case of inadequate data records, the patients were excluded from this study.

\subsection{Treatment Procedures}

A standard postendodontic protocol was generally used. The presence of a sufficient apical root filling of 4-5 mm and a minimum crown-to-post length ratio of 1:1 were aimed at considering the individual circumstances. The length was calculated based on the radiographic image and by the length of the root filling documented. The length of the post was measured at the level of the root canal entrance and, in a second step, correlated to the radiologically measured crown length.

There were no restrictions regarding the indications of the post systems or the later restoration.

\subsubsection{Cast Post-and-Core}

Indirectly and individually produced cast posts were used. After the application of the rubber dam and removal of the temporary filling, the coronal part of the gutta-percha filling was removed, and post drilling was performed with prefabricated pre-drills (Unimetric; Dentsply Sirona; York, PA, USA). The pre-post drilling was performed with the Uniclip system (Dentsply Maillefer; Tulsa, OK, USA). The main drilling was performed with a standardized post drill with an apical diameter of one millimeter. Using the three sizes with different lengths, the diameter of the coronal part could vary. The system-conform synthetic post was placed into the lumen after drilling. After pressing the placeholder into the final position, the impression was taken either with a polyether (Impregum; 3M Oral Care; Seefeld, Germany) or, in rare cases, with a burn-out material (Pattern Resin JS; GC; Tokyo, Japan). Pre-assembled Unimetric posts were used for temporary restoration. The materials used in the laboratory for the production of the individually cast post constructions were, on the one hand, a high gold content gold-platinum alloy and, on the other hand, a cheaper 
alternative made of non-precious metal. Both post and core were cast in one piece. Posts were either cemented with Harvard Cement (Harvard Dental International; Hoppegarten, Germany), RelyX Unicem (3M Oral Care; Seefeld, Germany), Ketac Cem (3M Oral Care; Seefeld, Germany) or Panavia F 2.0 (Kuraray Co.; Osaka, Japan).

\subsubsection{Fiber-Reinforced Composite Resin Post}

Radiopaque and conical quartz fiber posts were used in four sizes (DT Light Post (VDW, Munich, Germany) (diameter 1.25, 1.5, 1.8, $2.2 \mathrm{~mm}$ ). The so-called Double Taper Design (DT) describes a double taper with a smaller diameter in the apical third and a wider diameter in the coronal part. Initial drilling was made with the DT Universal Drill. The root canal was then enlarged with the help of the DT Finishing Drill. Posts could be cemented either with RelyX Unicem (3M Oral Care; Seefeld, Germany), Rebilda DC (VOCO; Cuxhaven, Germany) or Panavia F 2.0 (Kuraray Co.; Osaka, Japan).

\subsection{Variables, Treatment and Follow-Up Procedures}

Besides the patient's data (age and gender), the specific tooth and construction data were gathered. Tooth-specific variables included type of tooth, number of proximal contacts, type of antagonist, the height of remaining cavity wall and age of root filling. Constructionspecific data included the date of post insertion, post system, post length and post diameter. Furthermore, the type of definitive prosthetic restoration was taken into account.

All variables not listed on the questionnaire were gathered equally from the patients' records. Hence, the last current clinical status of the patient could be registered. The date of the post insertion and the last clinical status of the post-and-core restoration were defined as the observation period.

As part of the regular controls of the patient, complications, failures or post in situ were registered. The post placement was considered as a baseline for all further analysis. Biological (pain, endodontic complication, tooth mobility) and technical complications (post fracture, loss of retention, Debonding) were noted. Complications could either lead to a "restorable" or to a "non-restorable" failure. A restorable failure included the option of reinserting the abutment or rebuilding the entire postendodontic complex and was defined as loss of retention or fracture of a post. A non-restorable failure led to tooth extraction and was defined as vertical or horizontal root fracture, a non-restorable secondary caries or paro-endo lesions. Such failures included vertical or horizontal root fracture, non-restorable secondary caries or perio-endodontic lesion. An uncertain prognosis prior to insertion of a renewed restoration, resulting in the extraction of the tooth, was also considered as irreversible failure. Time (in months) between the post insertion and detection of failure was defined as observation time. If the post-anchored tooth was still in situ at the end of the observation period, it was defined as "survival." Baseline and follow-up data were summarized for each post system separately.

\subsection{Matched Pair Design}

For testing the difference between both post systems, a matched pair design was applied. Pairs of different post-anchored teeth based on the same tooth type and the same type of restoration in different patients were created. No consideration was given to the age or sex of the patients. Each CPC restored tooth was randomly assigned to an FRCP restored tooth. By building pairs, 324 teeth were examined, with $n=162$ being post-and-core restored and $n=162$ being cast post-and-core-restored with different degrees of hard-tissue loss considering the entire observation period. One hundred and nine of these pairs were followed up for at least one year. The primary study outcome was failure one year after the post insertion.

Sample size calculation was performed via a two-sided Mc Nemar's test with $5 \%$ as the level of significance, a power of $80 \%$, an expected difference in proportions in failure rates between groups of $7.5 \%$ and an expected proportion of discordant pairs of $8.5 \%$. These assumptions led to a required number of pairs of 94 . 


\subsection{Statistical Analysis and Data Processing}

The primary analysis was performed by determining the failure and survival rates after one year (relative frequencies) and illustrated in a contingency table. Mc Nemar's test was used to compare failure rates between the 109 pairs. The level of significance was set to $5 \%$.

In a second evaluation, tooth- and construction-specific variables were evaluated by means of descriptive statistics up to a period of six years, including 162 pairs. In an additional analysis, the survival rates up to 60 months were compared using Kaplan-Meier survival curve. Data analysis and graphical representation were performed by using IBM SPSS Statistics 25 (Ehningen, Germany) and R in Version 3.4.0 (R Core Team (2018). $\mathrm{R}$ : A language and environment for statistical computing. R Foundation for Statistical Computing, Vienna, Austria. URL https:/ / www.R-project.org/; 13 December 2021).

\section{Results}

Out of 162 CPC and FRCP matched pairs (Extended Table 1), 109 of these pairs could be followed up for at least one year. The followed-up matched pairs differed barely with respect to the age and gender of the study participants. For example, the median age of patients receiving CPC was 65 years and of patients receiving FRCP was 66 years. The excluded case pairs did not differ hardly. Here, the median age was also 65 for CPC and 62 for FRCP. The gender ratio also remained very similar. In the CPC group, 52 female and 57 male patients remained after one year. In the FRCP group, there were 58 females and 51 males. Slightly more female patients could not be followed up for more than one year (CPC: 32 females, 21 males; FRCP: 28 females, 25 males).

Table 1. Results for the primary endpoint.

\begin{tabular}{ccccc}
\hline & & \multicolumn{3}{c}{ FRCP } \\
\cline { 3 - 5 } & & Failure & Survival & In Total \\
\hline \multirow{3}{*}{ CPC } & Failure & $0(0 \%)$ & $10(9 \%)$ & 10 \\
\cline { 2 - 5 } & Survival & $4(4 \%)$ & $95(87 \%)$ & 99 \\
\cline { 2 - 5 } & In total & 4 & 105 & $109(100 \%)$
\end{tabular}

The number of failures and the percentage distribution (\%) are shown. There was no failure of both post systems occurred in matched pairs.

In the CPC-restored teeth, the radiologically measured length was more than $10 \mathrm{~mm}$ in 64 teeth and less than $10 \mathrm{~mm}$ in 29 teeth. In FRCP, the length was over $10 \mathrm{~mm}$ in 61 cases and less than $10 \mathrm{~mm}$ in 54 teeth (Table 2). For a total of 116 teeth, no reliable information on the post length could be determined and therefore could not be tabulated. Further analysis showed that in almost all cases, the posts were longer than or equal to the length of the restoration, and thus, the intended 1:1 ratio was obtained.

Table 2. Results of measured post length and post-crown ratio.

\begin{tabular}{ccc}
\hline & CPC & FRCP \\
\hline Post length $<10 \mathrm{~mm}$ & 64 & 61 \\
\hline Post length $\geq 10 \mathrm{~mm}$ & 29 & 54 \\
\hline Post length $>$ Crown height & 70 & 97 \\
\hline Post length $=$ Crown height & 15 & 30 \\
\hline Post length $<$ Crown height & 2 & 3
\end{tabular}

The post lengths less than and greater than $10 \mathrm{~mm}$ are shown. In addition, the pin-to-crown ratio was determined. In 116 cases, no reliable measurement could be obtained and could not be included in the table.

In the CPC group, 10 (9\%) of the analyzed teeth failure occurred one year after implantation, while the matched tooth in the FRCP group survived. Four $(4 \%)$ teeth in the FCRP group had a failure in the first year after implantation, while the matched teeth 
were without failure. Overall, in $87 \%$ (95) of all pairs, both teeth survived. There was no pair with failure for both teeth. In conclusion, no significant difference in the failure rates between CPC and FRCP could be found as the p-value (McNemar's test) was 0.1814 . Without looking at the matched pairs, $90 \%$ in the CPC group and $97 \%$ in the FRCP were without failure in the first year after implantation (OR $=0.4$ with $95 \%-K I$ : $(0.09 ; 1.39)$ ).

A logistic regression analysis evaluating the associations between several clinical parameters failed due to the low number of events (failure rate). A descriptive analysis of failures in comparison between the pairs shows some tendencies. It became apparent that premolars, followed by canines, had to be restored with posts most frequently. Relative to the number of teeth restored, more failures occurred with canines (Table 3). CPC in maxillary canines is considered to cause more frequent losses (3.2\%) than in other teeth types. In most cases, however, the teeth could be restored by re-cementing the posts. In comparison between fixed crowns and telescopic dentures, teeth restored with CPC and FRCP under telescopic dentures seem to lead to higher losses (4.6\%). In this context, the results that teeth without support by proximal contacts are riskier $(4.6 \%)$ do not seem surprising (Table 3).

Table 3. Descriptive data analysis.

\begin{tabular}{|c|c|c|c|c|c|c|}
\hline & \multirow{2}{*}{$\frac{\text { Survival }}{\text { total }}$} & \multirow{2}{*}{$\begin{array}{c}\text { Failure } \\
\text { total }\end{array}$} & \multicolumn{2}{|c|}{ Restorable Failure } & \multicolumn{2}{|c|}{ Unrestorable Failure } \\
\hline & & & $\mathrm{CPC}$ & FRCP & $\mathrm{CPC}$ & FRCP \\
\hline \multicolumn{7}{|l|}{ Tooth type } \\
\hline \multicolumn{7}{|l|}{ Upper jaw } \\
\hline Incisors & $18(8.2 \%)$ & $2(0.9 \%)$ & & & & 2 \\
\hline Canines & $39(17.9 \%)$ & $7(3.2 \%)$ & 6 & & 1 & \\
\hline Premolars & $36(16.5 \%)$ & $\begin{array}{c}2 \\
(0.9 \%)\end{array}$ & 1 & & 1 & \\
\hline Molars & $14(6.4 \%)$ & & & & & \\
\hline \multicolumn{7}{|l|}{ Lower jaw } \\
\hline Incisors & $\begin{array}{c}3 \\
(1.4 \%)\end{array}$ & $1(0.4 \%)$ & 1 & & & \\
\hline Canines & $24(11 \%)$ & & & & & \\
\hline Premolars & $56(25.7 \%)$ & $2(0.9 \%)$ & & & & 2 \\
\hline Molars & $14(6.4 \%)$ & & & & & \\
\hline \multicolumn{7}{|l|}{ Definitive restoration } \\
\hline Crown & $77(35.3 \%)$ & $3(1.4 \%)$ & 3 & & & \\
\hline Fixed partial denture & $22(10 \%)$ & & & & & \\
\hline Telescopic denture & $\begin{array}{c}88 \\
(40.4 \%)\end{array}$ & $10(4.6 \%)$ & 5 & & 2 & 3 \\
\hline Removable partial denture & $14(6.4 \%)$ & & & & & \\
\hline No prosthetic restoration & $\begin{array}{c}3 \\
(1.4 \%)\end{array}$ & $1(0.4 \%)$ & & & & 1 \\
\hline \multicolumn{7}{|l|}{ Number of proximal contacts } \\
\hline 0 & $\begin{array}{c}89 \\
(40.8 \%)\end{array}$ & $\begin{array}{c}9 \\
(4.1 \%)\end{array}$ & 5 & & 1 & 3 \\
\hline $1-2$ & $\begin{array}{c}115 \\
(52.7 \%)\end{array}$ & $\begin{array}{c}5 \\
(2.3 \%)\end{array}$ & 3 & 1 & & 1 \\
\hline
\end{tabular}

In this table, the matched pairs were categorized according to tooth type, their definitive restoration and the number of proximal contacts. The failures in number and (percent) are classified into restorable and unrestorable.

Concerning the whole data, within almost six years of observation, 35 failures could be observed in the cast post-core-system group and 17 failures in the fiber-reinforced composite resin posts. The most frequent causes of failure in the CPC group were the loss of post retention $(n=16)$ followed by root fracture $(n=7)$. A total of 15 teeth could 
be restored; 20 teeth resulted in tooth extraction (Table 4). Those survival rates up to 60 months were compared using Kaplan-Meier survival curves. In this analysis, a survival rate of $91.3 \%$ after one year is shown for CPC. After five years, the annual failure rate was determined to be $5.8 \%$ which led to a total survival rate of $64.5 \%$ with a loss to follow-up of 100 teeth (Figure 1A). Within five years, the annual failure rate for FRCP was determined to be $2.8 \%$, including a total survival rate of $79.3 \%$. one hundred and thirty-two teeth were not followed up completely to 60 months (Figure 1A).

Table 4. Proportion of failure rates and failure modes of the cast post-and-core system (CPC) and the fiber-reinforced composite resin posts (FRCP).

\begin{tabular}{ccccccc}
\hline Complication & \multicolumn{2}{c}{$\begin{array}{c}\text { No } \\
\text { Failure }\end{array}$} & \multicolumn{2}{c}{ Restorable Failure } & \multicolumn{2}{c}{ Unrestorable Failure } \\
& CPC & FRCP & CPC & FRCP & CPC & FRCP \\
\hline None & 127 & 145 & & & & \\
Post fracture & & & & 2 & & 6 \\
Loss of retention & & & 15 & & 1 & 1 \\
Apical ostitis & & & & & 3 & 1 \\
Tooth mobility & & & & & 7 & 2 \\
Root fracture & & & & 1 & 2 \\
Secondary caries & & & & 3 & 1 \\
Uncertain prognosis & & & & 4 & 2 \\
Pain & & & & & \\
\hline
\end{tabular}

A total of 35 failures occurred in the CPC group and 17 in the FRCP group. The type of each failure that occurred is shown in this table. Failures are classified as restorable and unrestorable.

A

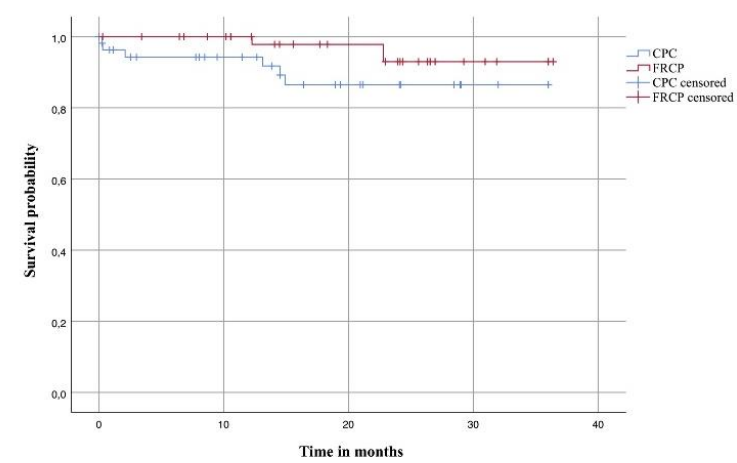

B
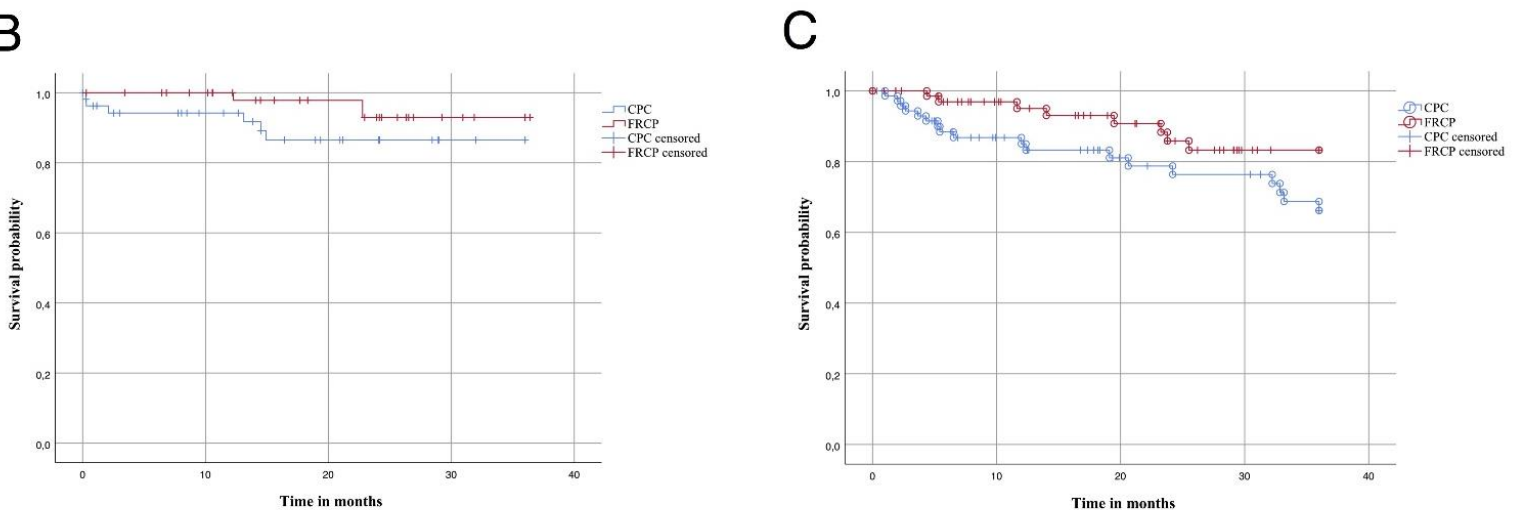

Figure 1. (A) Survival probabilities of the cast post-and-core (CPC) and the fiber-reinforced composite resin posts (FRCP), including all censored teeth after 60 months of observation. Kaplan-Meier plots of CPC and FRCP are shown. (B) CPC or FRCP treated single crowns and $(\mathbf{C})$ telescopic dentures up to 36 months are shown. 
Since the data for single crowns and telescopic dentures appeared noticeable in the previous descriptive data analysis, a Kaplan-Meier survival curve was also generated for these two restoration types. However, since there was a smaller number of cases, only an observation period of 36 months could be performed.

In CPC treated single crowns, failures were recorded after three years in 6 of 56 cases. The 3-year survival probability, in this case, was $86.5 \%$ (Figure 1B). For the fiber-reinforced system FRCP, failures were noted in 3 of 56 cases. No event occurred in 53 single crowns $(94.6 \%)$. The 3-year survival probability is, therefore, $92.9 \%$ (Figure 1B).

Higher values were described for telescopic dentures. For metallic post system CPC, failure occurred in 18 of 73 teeth. Fifty-five teeth (75.3\%) showed no event and were censored. In FRCP, failure was noted in 8 of 73 after three years. No event occurred in 65 single crowns $(89 \%)$. The 3-year survival probability was $66.2 \%$ for CPC and $83.2 \%$ for FRCP (Figure 1C).

\section{Discussion}

The available data suggest that the null hypothesis should be accepted since FRCP showed the same risk of failure compared to CPC, taking into account the definitive prosthetic restoration and tooth type within the observation period. Since there were fewer events than were assumed in the sample size calculation, a bigger number should have been analyzed. Of course, these difficulties also derived from the concept of a retrospective study in general. Here, data and patients may not be able to include in the study because of incomplete information. In order to minimize statistical bias, this study intended to create pairs based on the same tooth type and type of prosthetic restoration. Nevertheless, unknown confounding factors could remain unrecognized in this retrospective study.

It also seems conceivable that one post system was preferably used for severe or less severe tooth structure defects. This bias cannot be completely excluded with regard to the retrospective study design. At least, at the time of data collection, there were no restrictions regarding the indications of the post systems.

Unfortunately, it was not possible to follow up factors of existing tooth structure in our study. A prospective study design would be required to demonstrate explicit maintenance of the ferrule design in subsequent restorations. Following the ferrule design is described as a critical factor for the survival probability of a postendodontic complex [15-17]. Nevertheless, the comparison of the two post systems is important, as both techniques (CPC, FRCP) are part of the clinical standard.

Comparable studies have shown that post-restored anterior teeth are almost twice as likely to fail compared with posterior teeth [18-23]. Premolars were the most frequently restored tooth type (Table 1); however, the highest complication rates were found in maxillary anterior teeth and maxillary canines. In a prospective long-term study by Naumann et al., the overall failure rates for anterior teeth were comparable [21]. In their study, another important survival factor was the number of remaining cavity walls prior to restoration. Fifty-eight percent of teeth with no remaining cavity walls were affected by a failure within the observation of 10 years.

Based on matched pairs, it is not possible to retrospectively understand which post system was preferred in terms of prosthetic restoration. Although numerous studies have shown that neither post design, length or material play a crucial role in fracture probability [23-25], it seems plausible that the post material may influence the number of root fractures because of the different elastic modulus [7,11,13,26-28]. During a 4-yearobservation, Ferrari et al. reported that root fractures were the most frequent type of failure regarding the cast post-and-core system [29], whereas carbon fiber posts showed a lower percentage of root fractures. In the present study, seven teeth were fractured with the CPC within the entire observation period. Two root fractures were recorded within the FRCP (Table 3). This may be attributed to a more favorable stress distribution under loading, as the modulus of elasticity is similar to that of dentine [8,28-32]. Six of eight fiber-reinforced teeth could not be restored again due to post-fracture fractures. Therefore, the postulation 
of repeatability of teeth restored with this system is questionable [33]. Considering the remaining hard tissue, prosthetic value and perforation risk, clinicians in our study tended to opt for tooth extraction.

With regard to prosthetic restoration, post-anchored teeth were incorporated as telescopic abutments in telescopic prostheses (45\%). The second most common restoration was a single crown (35\%) (Table 3). An increased complication rate with combined fixedremovable dentures was described in several studies [34-36]. A recent study by Martino et al. showed that the type of restoration had a significant impact on post survival [23]. We observed similar results in our descriptive data analysis and Kaplan-Meier survival curves. It is apparent that telescopic crowns are more at risk of failure than post restorations under crowns. It seems natural that then also teeth without proximal contact $(22 \%)$ were found to fail more frequently than teeth with proximal contact $(10 \%)$ in both post systems, which was already shown in other studies $[37,38]$.

An even higher number of patients would have been necessary to verify the significance of the above trends. An organized follow-up with a previously longer observation period and a higher number of included patients seems reasonable to achieve higher statistical security in data analyzes. Nevertheless, the survival rates and causes of failure determined in our study show similarities with previously published studies [23,39-42].

\section{Conclusions}

Within the limitations of this study, the FRCP showed a lower failure risk compared to the $\mathrm{CPC}$, considering the definitive prosthetic restoration and tooth type within the observation period (not statistically significant). In the CPC group, retention loss and root fracture were frequent causes of failure. Regarding the FRCP, post-fracture was the most common reason for failure. In this study, endodontically treated teeth serving as abutments for telescopic dentures were more likely to be affected by failure compared to teeth restored with a single crown. Due to different study designs and differing criteria, a comparison of studies on survival probabilities of post-anchored teeth is difficult. Therefore, multicenter and methodologically comparable studies with differentiation of the relevant clinical parameters would be desirable.

Author Contributions: Writing—original draft preparation, O.B., D.I. and S.T.; validation, D.I.; formal analysis, D.I. and S.T.; visualization, O.B.; conceptualization and supervision, A.P. and C.B.-Z. All authors have read and agreed to the published version of the manuscript.

Funding: The research did not receive any grant from funding agencies in public, commercial or not-for-profit sectors.

Institutional Review Board Statement: The study was conducted according to the guidelines of the Declaration of Helsinki, The study was approved by the local ethical review committee of Witten/Herdecke University (approval number: 93/2017).

Informed Consent Statement: Informed consent was obtained from all subjects involved in the study.

Data Availability Statement: The data to this study can be shared upon reasonable request from the corresponding author.

Conflicts of Interest: The authors declare that they have no competing interest.

\section{References}

1. Juloski, J.; Radovic, I.; Goracci, C.; Vulicevic, Z.R.; Ferrari, M. Ferrule effect: A literature review. J. Endod. 2012, 38, 11-19. [CrossRef] [PubMed]

2. Theodosopoulou, J.N.; Chochlidakis, K.M. A systematic review of dowel (post) and core materials and systems. J. Prosthodont. 2009, 18, 464-472. [CrossRef] [PubMed]

3. Naumann, M.; Kiessling, S.; Seemann, R. Treatment concepts for restoration of endodontically treated teeth: A nationwide survey of dentists in Germany. J. Prosthet. Dent. 2006, 96, 332-338. [CrossRef] [PubMed]

4. Bialy, M.; Targonska, S.; Szust, A.; Wiglusz, R.J.; Dobrzynski, M. In Vitro Fracture Resistance of Endodontically Treated Premolar Teeth Restored with Prefabricated and Custom-Made Fibre-Reinforced Composite Posts. Materials 2021, 14, 6214. [CrossRef] 
5. Tronstad, L.; Asbjornsen, K.; Doving, L.; Pedersen, I.; Eriksen, H.M. Influence of coronal restorations on the periapical health of endodontically treated teeth. Endod. Dent. Traumatol. 2000, 16, 218-221. [CrossRef] [PubMed]

6. Fox, K.; Gutteridge, D.L. An in vitro study of coronal microleakage in root-canal-treated teeth restored by the post and core technique. Int. Endod. J. 1997, 30, 361-368. [CrossRef] [PubMed]

7. Peroz, I.; Blankenstein, F.; Lange, K.-P.; Naumann, M. Restoring endodonticall treated teeth with posts and cores-A review. Quintessence Int. 2005, 36, 737-745.

8. Duret, B.; Reynaud, M.; Duret, F. A new concept of corono-radicular reconstruction, the Composipost (2). Chir. Dent. Fr. 1990, 60, 69-77. [PubMed]

9. Bateman, G.; Ricketts, D.N.; Saunders, W.P. Fibre-based post systems: A review. Br. Dent. J. 2003, 195, 43-48; discussion 37. [CrossRef] [PubMed]

10. Schwartz, R.S.; Robbins, J.W. Post placement and restoration of endodontically treated teeth: A literature review. J. Endod. 2004, 30, 289-301. [CrossRef]

11. Marchionatti, A.M.E.; Wandscher, V.F.; Rippe, M.P.; Kaizer, O.B.; Valandro, L.F. Clinical performance and failure modes of pulpless teeth restored with posts: A systematic review. Braz. Oral Res. 2017, 31, e64. [CrossRef]

12. Morgano, S.M.; Brackett, S.E. Foundation restorations in fixed prosthodontics: Current knowledge and future needs. J. Prosthet. Dent. 1999, 82, 643-657. [CrossRef]

13. Zhou, L.; Wang, Q. Comparison of fracture resistance between cast posts and fiber posts: A meta-analysis of literature. J. Endod. 2013, 39, 11-15. [CrossRef] [PubMed]

14. Heydecke, G.; Peters, M.C. The restoration of endodontically treated, single-rooted teeth with cast or direct posts and cores: A systematic review. J. Prosthet. Dent. 2002, 87, 380-386. [CrossRef] [PubMed]

15. Naumann, M.; Schmitter, M.; Frankenberger, R.; Krastl, G. “Ferrule Comes First. Post Is Second!” Fake News and Alternative Facts? A Systematic Review. J. Endod. 2018, 44, 212-219. [CrossRef]

16. Sorensen, J.A.; Engelman, M.J. Ferrule design and fracture resistance of endodontically treated teeth. J. Prosthet. Dent. 1990, 63, 529-536. [CrossRef]

17. Stankiewicz, N.R.; Wilson, P.R. The ferrule effect: A literature review. Int. Endod. J. 2002, 35, 575-581. [CrossRef] [PubMed]

18. Bergman, B.; Lundquist, P.; Sjogren, U.; Sundquist, G. Restorative and endodontic results after treatment with cast posts and cores. J. Prosthet. Dent. 1989, 61, 10-15. [CrossRef]

19. Eckerbom, M.; Magnusson, T.; Martinsson, T. Prevalence of apical periodontitis, crowned teeth and teeth with posts in a Swedish population. Endod. Dent. Traumatol. 1991, 7, 214-220. [CrossRef] [PubMed]

20. Eckerbom, M.; Magnusson, T.; Martinsson, T. Reasons for and incidence of tooth mortality in a Swedish population. Endod. Dent. Traumatol. 1992, 8, 230-234. [CrossRef]

21. Naumann, M.; Koelpin, M.; Beuer, F.; Meyer-Lueckel, H. 10-year survival evaluation for glass-fiber-supported postendodontic restoration: A prospective observational clinical study. J. Endod. 2012, 38, 432-435. [CrossRef]

22. Naumann, M.; Reich, S.; Nothdurft, F.P.; Beuer, F.; Schirrmeister, J.F.; Dietrich, T. Survival of glass fiber post restorations over 5 years. Am. J. Dent. 2008, 21, 267-272.

23. Martino, N.; Truong, C.; Clark, A.E.; O’Neill, E.; Hsu, S.M.; Neal, D.; Esquivel-Upshaw, J.F. Retrospective analysis of survival rates of post-and-cores in a dental school setting. J. Prosthet. Dent. 2020, 123, 434-441. [CrossRef]

24. Fokkinga, W.A.; Kreulen, C.M.; Bronkhorst, E.M.; Creugers, N.H. Up to 17-year controlled clinical study on post-and-cores and covering crowns. J. Dent. 2007, 35, 778-786. [CrossRef] [PubMed]

25. Naumann, M.; Rosentritt, M.; Preuss, A.; Dietrich, T. The effect of alveolar bone loss on the load capability of restored endodontically treated teeth: A comparative in vitro study. J. Dent. 2006, 34, 790-795. [CrossRef]

26. Asmussen, E.; Peutzfeldt, A.; Heitmann, T. Stiffness, elastic limit, and strength of newer types of endodontic posts. J. Dent. 1999, 27, 275-278. [CrossRef]

27. Kinney, J.H.; Habelitz, S.; Marshall, S.J.; Marshall, G.W. The importance of intrafibrillar mineralization of collagen on the mechanical properties of dentin. J. Dent. Res. 2003, 82, 957-961. [CrossRef]

28. Mannocci, F.; Ferrari, M.; Watson, T.F. Intermittent loading of teeth restored using quartz fiber, carbon-quartz fiber, and zirconium dioxide ceramic root canal posts. J. Adhes. Dent. 1999, 1, 153-158. [PubMed]

29. Ferrari, M.; Vichi, A.; Garcia-Godoy, F. Clinical evaluation of fiber-reinforced epoxy resin posts and cast post and cores. Am. J. Dent. 2000, 13, 15B-18B. [PubMed]

30. Monticelli, F.; Goracci, C.; Ferrari, M. Micromorphology of the fiber post-resin core unit: A scanning electron microscopy evaluation. Dent. Mater. 2004, 20, 176-183. [CrossRef]

31. Glazer, B. Restoration of endodontically treated teeth with carbon fibre posts-A prospective study. J. Can. Dent. Assoc. 2000, 66, 613-618.

32. Lamichhane, A.; Xu, C.; Zhang, F.Q. Dental fiber-post resin base material: A review. J. Adv. Prosthodont. 2014, 6, 60-65. [CrossRef] [PubMed]

33. De Rijk, W.G. Removal of fiber posts from endodontically treated teeth. Am. J. Dent. 2000, 13, 19B-21B.

34. Rehmann, P.; Weber, A.; Wöstmann, B.; Ferger, P. Clinical evaluation of teeth fitted with telescope crowns for retaining a partial dentur. Dtsch. Zahnärztl. Z. 2007, 62, 99-103. 
35. Wegner, P.K.; Freitag, S.; Kern, M. Survival rate of endodontically treated teeth with posts after prosthetic restoration. J. Endod. 2006, 32, 928-931. [CrossRef] [PubMed]

36. Wostmann, B.; Balkenhol, M.; Weber, A.; Ferger, P.; Rehmann, P. Long-term analysis of telescopic crown retained removable partial dentures: Survival and need for maintenance. J. Dent. 2007, 35, 939-945. [CrossRef]

37. Aquilino, S.A.; Caplan, D.J. Relationship between crown placement and the survival of endodontically treated teeth. J. Prosthet. Dent. 2002, 87, 256-263. [CrossRef] [PubMed]

38. Caplan, D.J.; Kolker, J.; Rivera, E.M.; Walton, R.E. Relationship between number of proximal contacts and survival of root canal treated teeth. Int. Endod. J. 2002, 35, 193-199. [CrossRef]

39. Cagidiaco, M.C.; Garcia-Godoy, F.; Vichi, A.; Grandini, S.; Goracci, C.; Ferrari, M. Placement of fiber prefabricated or custom made posts affects the 3-year survival of endodontically treated premolars. Am. J. Dent. 2008, 21, 179-184.

40. Naumann, M.; Blankenstein, F.; Dietrich, T. Survival of glass fibre reinforced composite post restorations after 2 years-an observational clinical study. J. Dent. 2005, 33, 305-312. [CrossRef] [PubMed]

41. Schmitter, M.; Hamadi, K.; Rammelsberg, P. Survival of two post systems-Five-year results of a randomized clinical trial. Quintessence Int. 2011, 42, 843-850. [PubMed]

42. Schmitter, M.; Rammelsberg, P.; Gabbert, O.; Ohlmann, B. Influence of clinical baseline findings on the survival of 2 post systems: A randomized clinical trial. Int. J. Prosthodont. 2007, 20, 173-178. [PubMed] 